\title{
Repeated applications of CPPU on highbush blueberry cv. Duke increase yield and enhance fruit quality at harvest and during postharvest
}

\author{
Jorge B. Retamales ${ }^{1 *}$, Gustavo A. Lobos ${ }^{1}$, Sebastián Romero ${ }^{1}$, Ricardo Godoy ${ }^{1}$, and Claudia Moggia ${ }^{1}$
}

\begin{abstract}
Applications of N-(2-chloro-4-pyridyl)-N'-phenylurea (CPPU) can increase blueberry (Vaccinium corymbosum L.) yield and fruit size, but their impact on postharvest is unknown. We studied repeated CPPU applications effects on yield and quality (harvest, postharvest), over 2 yr on mature 'Duke' plants in South-Central Chile. The first year, 5 or $10 \mathrm{~mL} \mathrm{~L}{ }^{-1} \mathrm{CPPU}$ was applied at 3,10 , and/or $17 \mathrm{~d}$ after full bloom (DAFB) plus a non-sprayed control. The second year, 5 or $10 \mathrm{~mL} \mathrm{~L}^{-1} \mathrm{CPPU}$ were sprayed 10 and 17 DAFB plus a control. The first year, only $10 \mathrm{~mL} \mathrm{~L}^{-1}$ CPPU sprayed $3+17$ DAFB increased yield (32.5\% > control); $10 \mathrm{~mL} \mathrm{~L}^{-1}$ CPPU applied 10 or 3+17 DAFB had highest fruit diameter; and $10 \mathrm{~mL} \mathrm{~L}^{-1} \mathrm{CPPU}_{\text {at }} 17 \mathrm{DAFB}$ or at 3+10+17 DAFB had highest soluble solids. Overall, $10 \mathrm{~mL} \mathrm{~L}^{-1}$ CPPU applied 3+17 DAFB, was the best treatment for year one, since it increased fruit yield and diameter, while soluble solids and postharvest weight loss were similar to control. The second year, $10 \mathrm{~mL} \mathrm{~L}^{-1} \mathrm{CPPU}$ reduced fruit coloration (blue color coverage index: BCCI) and soluble solids, but not firmness at harvest. This rate increased berry weight $(24.2 \%)$ and fruit wax $(59 \%>$ wax coverage index: WCI) at harvest. Harvest and postharvest WCI increased consistently as CPPU rate increased. CPPU reduced fruit rotting (15\% at $45+5$ evaluation). During storage, CPPU-treated-fruit had a slower decrease in firmness $(30.5 \%<$ control at $30+1)$, but no difference at 30+5. CPPU-treated-fruit usually had higher post harvest soluble solids. Ten $\mathrm{mL} \mathrm{L}^{-1} \mathrm{CPPU}_{\text {retarded color }}$ evolution at harvest and at $30+1$, but not at $30+5,40+1$ or $40+5$.
\end{abstract}

Key words: Cytokinin, firmness, fruit rotting, fruit wax, growth regulators, long-term cold storage, Vaccinium corymbosum.

\section{INTRODUCTION}

The worldwide area planted with blueberries (Vaccinium corymbosum L.) has greatly increased in the last two decades (Brazelton, 2009). This improved availability of fruit has increased the demand for higher quality fruit with consumer preference being mainly decided by visual, textural, and flavor-related quality parameters. Visual quality includes fruit color and size. In blueberries it has been shown that fruit size is a better indicator of sensory visual quality than the intensity of color (Saftner et al., 2008). In addition, large fruit are easier and cheaper to harvest (Strik et al., 2003). Fruit size varies among cultivars and is also influenced by management practices (irrigation, pruning, and growth regulators).

Application of growth regulators can alter fruit size expansion through flower bud inhibition, flower and/ or fruit thinning, or increased fruit size. Currently there are no effective thinners for blueberries (Retamales and Hancock, 2012). Gibberellic acid $\left(\mathrm{GA}_{3}\right)$ has been shown to significantly inhibit flower bud formation and increase

${ }^{1}$ Universidad de Talca, Centro de Mejoramiento y Fenómica Vegetal, Casilla 747, Talca, Chile.

*Corresponding author (jretamal@utalca.cl).

Received: 22 August 2013.

Accepted: 30 January 2014.

doi:10.4067/S0718-58392014000200005 fruit size (Retamales et al., 2000; Black and Ehlenfeldt, 2007), but the industry has shown little interest in using this technology since application is near the harvest time of the previous season and this makes difficult to establish the final fruit count. Previous trials in other fruit crops (kiwifruit, apples, table grapes, olives, and persimmon), have demonstrated that a synthetic cytokinin known as CPPU (N-[2-chloro-4-pyridyl]-N'-phenylurea), markedly enhances fruit size when applied near bloom (Greene, 1989; Reynolds et al., 1992; Antognozzi et al., 1993a; 1993b; Sugiyama and Yamaki, 1995). CPPU applications have been tested extensively on rabbiteye blueberries (Vaccinium virgatum Aiton) both in greenhouse and fields in different seasons, varieties and rate/timing combinations (Merino et al., 2002; NeSmith, 2002; NeSmith and Adair, 2004; NeSmith, 2005; Serri and Hepp, 2006; Williamson and NeSmith, 2007; NeSmith, 2008). In rabbiteye varieties ('Brightwell', 'Climax' 'Bluebelle', 'Powderblue', 'Premier', and 'Tifblue') CPPU application increased berry size $(5-25 \%)$ and fruit set (20\%) (NeSmith and Adair, 2004; NeSmith, 2005; 2008). The effect on fruit set was greater in poor fruit set situations, such as low bee activity or when little overlap in bloom date occurred among varieties (NeSmith, 2008).

Only single CPPU application trials have been reported on northern highbush blueberries. The optimum window of application of CPPU in blueberries was established to 
be 7 to $21 \mathrm{~d}$ after $50 \%$ bloom, with the highest success being from an application made around $14 \pm 3 \mathrm{~d}$ after $50 \%$ bloom (NeSmith, 2008). In various blueberry producing areas, the bloom extends for a long period (Lyrene and Muñoz, 1997; Retamales and Hancock, 2012). The effectiveness of growth regulators depends markedly on the phenological phase of the reproductive organs (Stover and Greene, 2005), which implies that the performance of CPPU application in blueberries could be improved by repeated applications.

Despite the large number of studies on the effect of CPPU on blueberries, there have been no reports on the impact of CPPU applications on the postharvest life of the fruit. Given the recent expansion in international trade of blueberries it is important that management practices do not reduce the postharvest life of the fruit. This is particularly important in the case of Chilean blueberries where 30-60 d postharvest are required considering that nearly $95 \%$ of the fruit is shipped by boat to distant markets (Moggia et al., 2009).

In this context, the objective of this research was to study the effect of repeated CPPU sprays on blueberry yields and fruit quality both at harvest and after prolonged cold storage.

\section{MATERIALS AND METHODS}

\section{Plant material, climatic conditions and CPPU applications}

Trials were done with plants from a commercial planting located in Linares (35 $57^{\prime} 56^{\prime \prime} \mathrm{S}$; 71 $40^{\circ} 73$ " W), Chile. Plants of similar size, fruit load and condition that had been established in 2003 at $2.8 \times 0.8 \mathrm{~m}$ were chosen. Plants had no signs or symptoms of diseases or pests. They were drip irrigated as required with one line of emitters on each side of the plant; emitters were distanced at $40 \mathrm{~cm}$ within the line. Plants were planted on $20 \mathrm{~cm}$ high and $80 \mathrm{~cm}$ wide ridges. Blueberry fields were managed according to standards used for fresh export of blueberries.

In both seasons there was no rain within $72 \mathrm{~h}$ of CPPU applications or during the harvest period. Average minimum temperatures during the season ranged from $2{ }^{\circ} \mathrm{C}$ (bloom period) to $12^{\circ} \mathrm{C}$ (harvest period). Average maximum temperatures varied from $15^{\circ} \mathrm{C}$ (bloom period) to $26{ }^{\circ} \mathrm{C}$ (harvest season).

Sprays were done with a fan nozzle using a $15 \mathrm{~L}$ capacity knapsack sprayer (SOLO, Santiago, Chile). In each season, sprayer calibration was done before application to ensure adequate coverage.

\section{Experimental conditions for first season: 2008-2009}

The treatments applied were the combination of two CPPU (CPPU 0.1 SL, ANASAC, Santiago, Chile) doses ( 5 or $10 \mathrm{~mL}^{2} \mathrm{~L}^{-1}$ ), and different number of applications (1, 2, or 3) during the season, applied at 3, 10, and/or 17 DAFB. Thus, this set of trials considered 15 treatments (14 with CPPU +1 control with no application; Table 1 ).

Six hand harvests were done every 5-7 d. Fruit were hand harvested at the peak of the season when they had at least $50 \%$ of the fruit surface covered with blue color. Total weight of harvested fruit was determined at each harvest with an electronic balance (LSV, Veto, Santiago, Chile).

Soluble solids (Atago Digital refractometer, Pocket PAL-1; Tokyo, Japan) and diameter (Bull Tools, China) were measured in harvests 2 and 4, on a total of 40 fruit chosen at random per replicate and per treatment.

To estimate weight loss in storage, a sample of 100 fruit per replicate and treatment were randomly collected in harvest 3 . These fruit were stored within $3 \mathrm{~h}$ at $4{ }^{\circ} \mathrm{C}$ and $80-85 \%$ RH for $25 \mathrm{~d}$. The initial and final weight of those fruit was measured with the electronic balance.

Experimental conditions for second season: 2009-2010 Three treatments were included for this season: CPPU

Table 1. Effects of the application of CPPU in different dosages, timing, and number of applications on yield, average fruit diameter (five harvests), and soluble solids (two harvests) of mature 'Duke' plants. Treatment: Application dates = 3, 10, and/or 17 d after full bloom (DAFB), and doses $=5$ or $10 \mathrm{~mL} \mathrm{~L}{ }^{-1}$. First season.

\begin{tabular}{|c|c|c|c|c|c|c|}
\hline $\begin{array}{l}\text { Date }(\mathrm{DAFB}) / \\
\text { dose }\left(\mathrm{mL} \mathrm{L}^{-1}\right)\end{array}$ & $\begin{array}{l}\text { Yield per } \\
\text { plant }\end{array}$ & $\begin{array}{c}\text { Difference from } \\
\text { control }\end{array}$ & $\begin{array}{c}\text { Fruit } \\
\text { diameter }\end{array}$ & $\begin{array}{l}\text { Difference } \\
\text { from control }\end{array}$ & $\begin{array}{c}\text { Soluble } \\
\text { solids }\end{array}$ & $\begin{array}{c}\text { Difference from } \\
\text { control }\end{array}$ \\
\hline & $\mathrm{kg}$ & $\%$ & $\mathrm{~mm}$ & $\%$ & ${ }^{\circ}$ Brix & $\%$ \\
\hline Control & $5.75 \mathrm{bcd}$ & 0.0 & $13.2 \mathrm{fg}$ & 0.0 & $11.0 \mathrm{~cd}$ & 0.0 \\
\hline $3 / 5$ & $6.17 \mathrm{abc}$ & 7.5 & $13.2 \mathrm{fg}$ & 0.2 & $10.8 \mathrm{cde}$ & -1.6 \\
\hline $10 / 5$ & $6.87 \mathrm{abc}$ & 19.6 & $13.1 \mathrm{fg}$ & -0.2 & $10.3 \mathrm{ef}$ & -5.7 \\
\hline $17 / 5$ & $7.08 \mathrm{ab}$ & 23.3 & $13.3 \mathrm{ef}$ & 1.1 & $10.9 \mathrm{~cd}$ & -1.0 \\
\hline $3,10 / 5$ & $6.98 \mathrm{ab}$ & 21.5 & $13.5 \mathrm{cde}$ & 2.5 & $10.7 \mathrm{de}$ & -2.7 \\
\hline $3,17 / 5$ & $5.95 \mathrm{abc}$ & 3.5 & 13.6bcd & 3.2 & $11.2 \mathrm{bc}$ & 2.3 \\
\hline $10,17 / 5$ & $5.16 \mathrm{~cd}$ & -10.2 & $13.4 \mathrm{cdef}$ & 1.6 & $10.7 \mathrm{cde}$ & -2.0 \\
\hline $3,10,17 / 5$ & $6.45 \mathrm{abc}$ & 12.3 & $13.0 \mathrm{gh}$ & -1.4 & $10.7 \mathrm{de}$ & -2.4 \\
\hline $3 / 10$ & $5.72 \mathrm{bcd}$ & -0.4 & $12.9 \mathrm{~h}$ & -2.2 & $10.8 \mathrm{cde}$ & -1.5 \\
\hline $10 / 10$ & $6.12 \mathrm{abc}$ & 6.5 & $14.2 \mathrm{a}$ & 7.5 & $10.8 \mathrm{~cd}$ & -1.1 \\
\hline $17 / 10$ & $5.34 \mathrm{bcd}$ & -7.0 & $13.3 \mathrm{def}$ & 1.2 & $11.8 \mathrm{a}$ & 7.3 \\
\hline $3,10 / 10$ & $5.85 \mathrm{bcd}$ & 1.8 & $13.6 \mathrm{bc}$ & 3.3 & $11.1 \mathrm{bcd}$ & 1.3 \\
\hline $3,17 / 10$ & $7.61 \mathrm{a}$ & 32.5 & $13.8 \mathrm{~b}$ & 4.7 & $11.2 \mathrm{bc}$ & 2.2 \\
\hline $10,17 / 10$ & $6.12 \mathrm{abc}$ & 6.5 & $13.2 \mathrm{efg}$ & 0.4 & $9.8 \mathrm{f}$ & -10.1 \\
\hline $3,10,17 / 10$ & $4.18 \mathrm{~d}$ & -27.3 & $12.8 \mathrm{~h}$ & -3.2 & $11.5 \mathrm{ab}$ & 5.0 \\
\hline Significance & $* *$ & - & $* * *$ & - & $* * *$ & - \\
\hline
\end{tabular}

Means followed by the same letter, within columns, are not significantly different according to Duncan`s multiple range test (P $\leq 0.05$ ).

$* *$, ***: significant at $\mathrm{P} \leq 0.01$ or 0.001 , respectively. A minus sign before each figure indicates a negative effect. 
applied at 10 and 17 DAFB at either 10 or $5 \mathrm{~mL} \mathrm{~L}^{-1}$, plus a control (no application).

Fruit were hand harvested at the peak of the season. Fruit weight was determined with electronic balance. Evaluations were done at harvest, after $30 \mathrm{~d}$ cold storage $\left(1^{\circ} \mathrm{C}\right)+1 \mathrm{~d}$ at room temperature $(30+1)$, as well as $30+5,45+1$, and $45+5$. On each evaluation, 200 fruit per replicate were used to determine wax coverage and color. A wax coverage index (WCI) was calculated similarly to the superficial apple scald index reported by Lurie et al. (1989). For that three categories were established based on visual assessment of the fruit: Cat. 1 (67-100\% wax coverage), Cat. 2 (34-66 wax coverage), and Cat. 3 (0-33 wax coverage). Then, the percentage of fruit in each category was multiplied by a factor which corresponded to 3,2, and 1, respectively. The formula used to calculate WCI was:

$(\%$ fruit Cat. $1 \times 3)+(\%$ fruit Cat $.2 \times 2)+$ $(\%$ fruit Cat. $3 \times 1) / 3$

Additionally, on each evaluation, blue color coverage (BCC) was rated as: range $1(90-100 \% \mathrm{BCC})$, range 2 (80-89\% BCC), range 3 (70-79\% BCC), range 4 (60-69\% $\mathrm{BCC})$, or range 5 (50-59\% BCC). Then, as done previously for WCI, a BCC index (BBCI) was calculated considering the proportion of fruit in each range (\% fruit R1, to \% fruit R5), and multiplied by a factor which corresponded to 5 , 4, 3, 2 or 1, for R1 to R5, respectively. Thus, the formula used to calculate BCCI was as follows:

$[(\%$ fruit R1 $\times 5)+(\%$ fruit R2 $\times 4)+(\%$ fruit R3 $\times 3)+$ $(\%$ fruit R4 $\times 2)+(\%$ fruit R5 $\times 1)] / 5$

Firmness was measured with a FirmTech 2 (BioWorks, Wamego, Kansas, USA) on 60 fruit per replicate. As reported by Ehlenfeldt and Martin (2002) and Saftner et al. (2008), the equipment was set up with maximum and minimum compression forces of $200 \mathrm{~g}(1.96 \mathrm{~N})$ and $15 \mathrm{~g}(0.15 \mathrm{~N})$, respectively; also, the speed of the piston was configured at $6 \mathrm{~mm} \mathrm{~s}^{-1}$. Soluble solids were assessed using 12 samples per replicate with a digital refractometer (Atago Model Pocket PAL-1, Tokyo, Japan). Rotting was evaluated visually on 200 fruit per replicate; values were expressed as a percentage.

\section{Experimental design, set up and data analysis}

A completely randomized design was used with four replicates of four plants each. The two plants in the center of each experimental unit were used for fruit sampling.

Data were subjected to ANOVA. For variables that were significant, mean separation $(\mathrm{p} \leq 0.05)$ was done with Duncan`s (in season 1) and LSD (in season 2). All analyses were performed with Statgraphics Centurion statistical software (Statpoint, Warrenton, Virginia, USA).

\section{RESULTS}

\section{First season: 2008-2009}

Only the application of $10 \mathrm{~mL} \mathrm{~L}^{-1} \mathrm{CPPU}$ when done at both 3 and 17 DAFB significantly increased fruit yield per plant with respect to control $32.5 \%$ greater; Table 1). As compared to the control, fruit diameter was both negatively (- sign) and positively affected by CPPU treatments, with the highest positive impact with $10 \mathrm{~mL}$ $\mathrm{L}^{-1}$ CPPU applied 10 DAFB $(7.5 \%>$ control $)$ and $10 \mathrm{~mL}$ $\mathrm{L}^{-1}$ CPPU applied 3 and 17 DAFB $(4.7 \%>$ control). The majority of treatments (9 out of 14) had negative impacts on soluble solids, with the highest significant and positive effect over the control being shown after applying $10 \mathrm{~mL}$ $\mathrm{L}^{-1} \mathrm{CPPU}$ at $17 \mathrm{DAFB}(7.3 \%>$ control $)$ and the application of $10 \mathrm{~mL} \mathrm{~L}^{-1}$ CPPU sprayed 3, 10, and 17 DAFB (5\% > control) (Table 1). The triple application of CPPU had the lowest yield, although not significantly lower than control $(27.5 \%<$ control); however, fruit diameter for this treatment was significantly lower than control $(3.2 \%<$ control). There were no differences among treatments in weight loss after $25 \mathrm{~d}$ at $4{ }^{\circ} \mathrm{C}$; values ranged between $6.7 \%$ for control fruit and $5.0 \%$ for $10 \mathrm{~mL} \mathrm{~L}^{-1} \mathrm{CPPU}$ applied at 10 and 17 DAFB (data not shown). Overall, the treatment of $10 \mathrm{~mL} \mathrm{~L}^{-1}$ applied both at 3 and 17 DAFB to 'Duke' appeared as the most promising, since it increased both fruit yield and diameter, and had soluble solids similar to the control fruit (Table 1).

\section{Second season: $2009-2010$}

Evaluations at harvest. As compared to control the most evident effect for CPPU at high rate $\left(10 \mathrm{~mL} \mathrm{~L}^{-1}\right)$ were increased berry weight (24.3\%; Table 2) and fruit wax coverage (Table 3; Figure 1). CPPU at $10 \mathrm{~mL} \mathrm{~L}^{-1}$ reduced both fruit color (Table 4) and soluble solids at harvest (data not shown). Fruit firmness at harvest was not affected by treatments (Table 2).

Table 2. Effect of dose of CPPU ( 5 or $\left.10 \mathrm{~mL} \mathrm{~L}^{-1}\right)$ applied at 10 and 17 $d$ after full bloom on 'Duke' blueberry plants in terms of fruit weight and firmness at harvest $(0)$ or after $30 \mathrm{~d}$ cold storage plus 1 or $5 \mathrm{~d}$ at room temperature $\left(25^{\circ} \mathrm{C}\right)(30+1$ or $30+5)$. Second season.

\begin{tabular}{lcccc}
\hline & $0 \mathrm{~d}$ & $0 \mathrm{~d}$ & $30+1 \mathrm{~d}$ & $30+5 \mathrm{~d}$ \\
\cline { 2 - 5 } Dose & Weight & \multicolumn{4}{c}{ Fruit firmness } \\
\hline $\mathrm{mL} \mathrm{L}^{-1}$ & $\mathrm{~g}$ & 204.5 & $151.9 \mathrm{a}$ & $89.5 \mathrm{a}$ \\
10 & $2.20 \mathrm{a}$ & 206.5 & $143.2 \mathrm{a}$ & $77.9 \mathrm{~b}$ \\
5 & $1.87 \mathrm{~b}$ & 212.0 & $115.5 \mathrm{~b}$ & $83.5 \mathrm{ab}$ \\
Control & $1.77 \mathrm{c}$ & 0.916 & 0.028 & 0.007 \\
p-value & 0.00001 & & & \\
\hline
\end{tabular}

For each evaluation date, means with similar letters do not differ significantly according to LSD test $(\mathrm{p} \leq 0.05)$.

Table 3. Effect of CPPU dose $\left(5\right.$ or $\left.10 \mathrm{~mL} \mathrm{~L}^{-1}\right)$ applied at 10 and $17 \mathrm{~d}$ after full bloom on wax coverage index (WCI) of 'Duke' blueberry fruits. WCI values near 100 represent higher proportion of fruit with 67-100\% wax coverage. Measurements done at harvest $(0)$ or after 30 or $45 \mathrm{~d}$ cold storage $\left(1^{\circ} \mathrm{C}\right)$ plus 1 or $5 \mathrm{~d}$ at room temperature $\left(25^{\circ} \mathrm{C}\right)$ $(30+1,30+5,40+1,40+5)$. Second season.

\begin{tabular}{lccccc}
\hline Dose & \multicolumn{5}{c}{ WCI at various dates $(\mathrm{d})$} \\
\hline $\mathrm{mL} \mathrm{L}^{-1}$ & 0 & $30+1$ & $30+5$ & $45+1$ & $45+5$ \\
10 & $81.6 \mathrm{a}$ & $84.5 \mathrm{a}$ & $84.7 \mathrm{a}$ & $83.8 \mathrm{a}$ & $83.0 \mathrm{a}$ \\
5 & $66.7 \mathrm{~b}$ & $66.6 \mathrm{~b}$ & $65.4 \mathrm{~b}$ & $67.1 \mathrm{~b}$ & $66.5 \mathrm{~b}$ \\
Control & $51.2 \mathrm{c}$ & $52.4 \mathrm{c}$ & $50.9 \mathrm{c}$ & $52.3 \mathrm{c}$ & $50.5 \mathrm{c}$ \\
$\mathrm{p}$-value & 0.00006 & 0.000001 & 0.000001 & 0.000001 & 0.000001 \\
\hline
\end{tabular}

$\overline{\text { For each evaluation date, means with similar letters do not differ }}$ significantly according to LSD test $(\mathrm{p} \leq 0.001)$. 


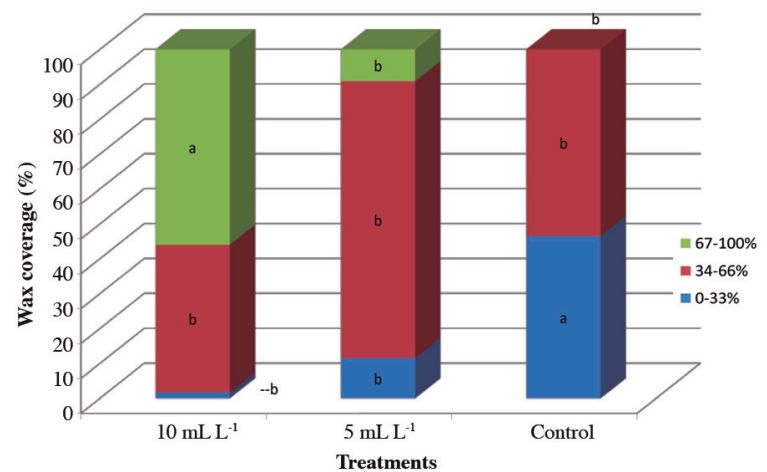

Similar letters for each category indicate they do not differ significantly according to LSD test $(\mathrm{p} \leq 0.05)$.

Figure 1. Effect of CPPU sprays (5 or $\left.10 \mathrm{~mL} \mathrm{~L}^{-1}\right)$ on the proportion of 'Duke' fruit in three wax coverage categories at harvest (Cat. $1=$ $67-100 \%$; Cat. $2=34-66 \%$; Cat. $3=0-33 \%$ ). Second season.

Table 4. Effect of CPPU dose ( 5 or $10 \mathrm{~mL} \mathrm{~L}^{-1}$ ) applied at 10 and 17 d on blue color coverage index (BCCI) on 'Duke' blueberry fruits. BCCI values near 100 represent higher proportion of fruit with 90 $100 \%$ bloom coverage. Measurements done at harvest (0) or after 30 or $45 \mathrm{~d}$ cold storage $\left(1^{\circ} \mathrm{C}\right)$ plus 1 or $5 \mathrm{~d}$ at room temperature $\left(25^{\circ} \mathrm{C}\right)$ $(30+1,30+5,40+1,40+5)$. Second season.

\begin{tabular}{lccccc}
\hline Dose & \multicolumn{5}{c}{ Color index at various dates (d) } \\
\hline $\mathrm{mL} \mathrm{L}^{-1}$ & 0 & $30+1$ & $30+5$ & $45+1$ & $45+5$ \\
10 & $93.4 \mathrm{~b}$ & $97.6 \mathrm{~b}$ & 97.0 & 96.4 & 98.3 \\
5 & $97.5 \mathrm{a}$ & $99.4 \mathrm{a}$ & 99.3 & 98.8 & 98.2 \\
Control & $98.3 \mathrm{a}$ & $98.4 \mathrm{ab}$ & 99.3 & 99.2 & 99.1 \\
p-value & 0.0001 & 0.03 & 0.07 & 0.07 & 0.3
\end{tabular}

For each evaluation date, means with similar letters do not differ significantly according to LSD test ( $\mathrm{p} \leq 0.001)$.

Postharvest evaluations. Wax coverage index increased throughout storage on CPPU-treated fruit. The magnitude of the effect was directly related to CCPU concentration; thus, WCI was highest with $10 \mathrm{~mL} \mathrm{~L}^{-1}$, intermediate with $5 \mathrm{~mL} \mathrm{~L}^{-1}$, and lowest for the control (Table 3 ).

Fruit color development was significantly reduced by $10 \mathrm{~mL} \mathrm{~L}^{-1} \mathrm{CPPU}$ at harvest, and this trend was again observed at the $30+1$ evaluation, but no differences among treatments were found at $30+5,40+1$ and $40+5$ (Table 4).

The application of CPPU significantly reduced fruit rotting (Table 5). No rotting was detected after $30+1 \mathrm{~d}$; however in the other postharvest evaluations $(30+5,45+1$, $45+5)$, rotting was significantly and consistently reduced by CPPU treatments, with lowest decay observed at the highest CPPU rate (Table 5). In comparison to control, fruits treated with CPPU had reduced firmness loss at $30+1(<30.5 \%)$ but not at 30+5 (Table 2).

Table 5. Effect of dose of CPPU ( 5 or $10 \mathrm{~mL} \mathrm{~L}^{-1}$ ) applied at 10 and 17 d after full bloom on 'Duke' blueberries fruit rotting (\%) after 30 or $45 \mathrm{~d}$ cold storage plus 1 or $5 \mathrm{~d}$ at room temperature $\left(25^{\circ} \mathrm{C}\right)(30+1$ or $30+5)$. Second season.

\begin{tabular}{lcccc}
\hline Dose & \multicolumn{4}{c}{ Rotting $(\%)$ at various dates $(\mathrm{d})$} \\
\hline $\mathrm{mL} \mathrm{L}^{-1}$ & $30+1$ & $30+5$ & $45+1$ & $45+5$ \\
10 & 0 & $1.5 \mathrm{a}$ & $6.9 \mathrm{a}$ & $10.3 \mathrm{a}$ \\
5 & 0 & $3.9 \mathrm{~b}$ & $11.1 \mathrm{~b}$ & $13.9 \mathrm{~b}$ \\
Control & 0 & $8.6 \mathrm{c}$ & $20.3 \mathrm{c}$ & $25.9 \mathrm{c}$ \\
p-value & & 0.0002 & 0.0001 & 0.0001 \\
\hline
\end{tabular}

For each evaluation date, means with similar letters do not differ significantly according to LSD test $(\mathrm{p} \leq 0.05)$.

\section{DISCUSSION}

\section{Yield and fruit size at harvest}

In our trials, the only treatment that significantly increased fruit yield per plant with respect to control (32.5\% greater) was $10 \mathrm{~mL} \mathrm{~L}^{-1}$ CPPU when applied on two occasions, at 3 and 17 DAFB. Serri and Hepp (2006) applied $10 \mathrm{~mL}$ $\mathrm{L}^{-1}$ CPPU once between 10 and $15 \mathrm{~d}$ after $50 \%$ bloom to 'Elliott' and 'Lateblue' northern highbush blueberries in Chile; they obtained a $20 \%$ and $50 \%$ increase in fruit weight, respectively. Within each variety, they reported that the number of fruits were similar in the CPPU and control treatments (no CPPU applied), which implies that yield increases for both varieties in response to CPPU were mainly due to improvements in fruit weight. In our trial for the first season, the largest increases in fruit diameter were obtained with the application of $10 \mathrm{~mL}$ $\mathrm{L}^{-1}$ at $10 \mathrm{DAFB}$ and also $10 \mathrm{~mL} \mathrm{~L}^{-1}$ at 3 and $17 \mathrm{DAFB}$, with $7.5 \%$ and $4.7 \%$ greater diameter than control fruit. Our results for the second season confirmed these results as fruit weight was increased $24 \%$ by $10 \mathrm{~mL} \mathrm{~L}^{-1} \mathrm{CPPU}$ applied at 10 and 17 DAFB.

\section{Fruit wax coverage}

It would be expected that increases in fruit size due to CPPU applications would decrease wax deposits as fruit expands. On the other hand, Williamson and NeSmith (2007) demonstrated that CPPU increases fruit size through cell expansion and division. This increase in cell number could be related to greater wax deposition on the fruit surface, as it has been reported that epidermal cells are linked to lipid synthesis (Post-Beittenmiller, 1996). In our trials, WCI was higher in fruit that received CPPU sprays and this was related to CPPU concentrate.

\section{Fruit quality at harvest}

A slight reduction in the accumulation of soluble solids and development of color was detected at harvest in CPPU-treated-fruit $(<1.5 \%)$. CPPU-treated-fruit showed greater soluble solids in postharvest. Perkins-Veazie et al. (1995) found that soluble solids did not differ greatly among clones and between fresh fruit and that stored for $21 \mathrm{~d}$ at $5{ }^{\circ} \mathrm{C}$ plus $1 \mathrm{~d}$ at $20{ }^{\circ} \mathrm{C}$. In part, the slower build up of soluble solids and color evolution could be due to the delay in ripening which is usually observed after CPPU sprays (Williamson and NeSmith, 2007).

\section{Postharvest fruit quality}

To our knowledge no reports have been published on the effect of CPPU on decay of blueberries. Our results show that CPPU significantly reduced decay in postharvest (up to $15 \%$ with highest dose). Even though it was shown many years ago that the main point for infections to enter into blueberry fruit was the stem-end scar (Cappellini and Ceponis, 1977), it is possible that this increased wax coverage could provide CPPU-treated-fruit with a 
physical barrier to drastically reduce pathogen infection (Duan et al., 2008). This greater wax coverage, caused by CPPU treatments, could also explain why fruit with greater diameter had similar fruit weight loss in storage during the first season.

Although in our study fruit firmness dropped during cold storage and shelf life, the effect should not be attributed to CPPU, since when firmness levels after shelf life $(30+5)$ were compared with those at harvest, the reduction in firmness for control fruit $(61 \%)$ was similar to that of $5 \mathrm{~mL} \mathrm{~L}^{-1}$-CPPU-treated-fruit $(62 \%)$ and higher than $10 \mathrm{~mL} \mathrm{~L}^{-1}$ fruit $(41 \%)$. This loss in firmness during storage of highbush blueberries was observed previously by Chiabrando et al. (2009). Firmness was slightly lower in our trials than those reported previously for 'Duke' (Yang et al., 2009), although they stored fruit only up to $3 \mathrm{wk}$. Also, even though these authors used the same firmness measuring equipment that we employed in our trials (FirmTech 2), they did not report the settings in their device, and this technical feature has shown to influence firmness readings (Ehlenfeldt and Martin, 2002).

\section{CONCLUSIONS}

In conclusion these trials provide evidence that depending on rate, dose and number of sprays, repeated CPPU applications can increase yield and diameter of 'Duke' highbush blueberry. The beneficial effects of this growth regulator were extended to the postharvest period, with greater wax deposition and, probably as a consequence, a significant and consistent reduction in both fruit rotting and weight loss. Even though positive results were obtained over two seasons, these trials need to be validated in other highbush blueberry cultivars.

\section{ACKNOWLEDGEMENTS}

Thanks to FONDEF (Project D09R1008) and ANASAC for financial assistance, as well as Professor PDS Caligari for critical review of the article.

\section{LITERATURE CITED}

Antognozzi, E., F. Famiani, A. Palliotti, and A. Tombesi. 1993a. Effects of CPPU (cytokinin) on kiwifruit productivity. Acta Horticulturae 329:150-152.

Antognozzi, E., P. Proietti, and M. Boco. 1993b. Effect of CPPU (cytokinin) on table olive cultivars. Acta Horticulturae 329:153155.

Black, B.L., and M.K. Ehlenfeldt. 2007. Foliar applications of $\mathrm{GA}_{4+7}$ reduce flowering in highbush blueberry. HortScience 42:555-558.

Brazelton, C. 2009. World blueberry acreage and production report. United States Highbush Blueberry Council - Industry Relations Committee, Folsom, California, USA.

Cappellini, R.A., and M.J. Ceponis. 1977. Vulnerability of stem-end scars of blueberry fruits to postharvest decays. Phytopathology $67: 118-119$
Chiabrando, V., G. Giacalone, and L. Rolle. 2009. Mechanical behavior and quality traits of highbush blueberry during postharvest storage. Journal of the Science of Food and Agriculture 89:989-992.

Duan, J., R. Wu, B. Strik, and Y. Zhao. 2008. Effect of edible coatings on the quality of fresh blueberries (Duke and Elliott) under commercial storage conditions. Postharvest Biology and Technology 59:71-79.

Ehlenfeldt, M., and R.B. Martin Jr. 2002. A survey of fruit firmness in highbush blueberry and species introgressed blueberry cultivars. HortScience 37:386-389.

Greene, D.W. 1989. CPPU influences 'McIntosh' apple crop load and fruit characteristics. HortScience 24:94-96.

Lyrene, P.M., and C. Muñoz. 1997. Blueberry production in Chile. Journal of Small Fruit and Viticulture 5:1-20.

Merino, R., H. Serri, and J. Holzapfel. 2002. Effect of GA3 and CPPU on fruit of 'Tifblue' rabbiteye blueberry (Vaccinium ashei R.) Acta Horticulturae 574:239-243.

Moggia, C., J.B. Retamales, G.A. Lobos, y P.D.S. Caligari. 2009. Arándanos en Chile: ¿Un futuro azul o gris? Revista Frutícola (Chile) 3:50-53.

NeSmith, D.S. 2002. Response of rabbiteye blueberry (Vaccinium ashei Reade) to the growth regulators CPPU and gibberellic acid. HortScience 37:666-668.

NeSmith, D.S. 2005. Use of plant growth regulators in blueberry production in the southeastern U.S.: A review. International Journal of Fruit Science 5:41-52.

NeSmith, D.S. 2008. Effect of timing of CPPU applications on rabbiteye blueberries. HortScience 43:1446-1448.

NeSmith, D.S., and H.M. Adair. 2004. Rabbiteye blueberry field trials with growth regulator CPPU. Small Fruit Review 3:183-191.

Perkins-Veazie, P., J. Clark, J. Collins, and J. Magee. 1995. Southern highbush blueberries clones differ in postharvest fruit-quality. Fruit Varieties Journal 49:46-52.

Post-Beittenmiller, D. 1996. Biochemistry and molecular biology of wax production in plants. Annual Review of Plant Physiology and Plant Molecular Biology 47:405-430.

Retamales, J.B., and J.F. Hancock. 2012. Blueberries. CABI, Cambridge, Massachusetts, USA.

Retamales, J.B., E.J. Hanson, and M.J. Bukovac. 2000. GA 3 as a flowering inhibitor in blueberries. Acta Horticulturae 527:147152.

Reynolds, A.G., D.A. Wardle, C. Zurowski, and N.E. Looney. 1992. Phenylureas, CPPU and thidiazuron affect yield components, fruit composition, and storage potential of four seedless grape selections. Journal of the American Society for Horticultural Science 117:85-89.

Saftner, R., J. Polascock, M.K. Ehlenfeldt, and B. Vinyard. 2008. Instrumental and sensory quality characteristics of blueberry fruit from twelve cultivars. Postharvest Biology and Technology 49:19-26.

Serri, H., and R. Hepp. 2006. Effect of the growth regulator CPPU on fruit quality and fruit ripening of highbush blueberries. Acta Horticulturae 715:279-282.

Stover, E.W., and D.W. Greene. 2005. Environmental effects on the performance of foliar applied plant growth regulators: a review focusing on tree fruits. HortTechnology 15:214-221.

Strik, B., G. Buller, and E. Hellman. 2003. Pruning severity affects yield, berry weight and hand harvest efficiency of highbush blueberry. HortScience 38:196-199.

Sugiyama, N., and Y.T. Yamaki. 1995. Effects of CPPU on fruit set and fruit growth in Japanese persimmon. Scientia Horticulturae $80: 337-343$

Williamson, J.G., and D.S. NeSmith. 2007. Effects of CPPU applications on southern highbush blueberries. HortScience 42:1612-1615.

Yang, W., J. Harpole, C. Finn, and B. Strik. 2009. Evaluating berry firmness and total soluble solids of newly released highbush blueberry cultivars. Acta Horticulturae 810:863-867. 